\title{
Article
}

\author{
Doi 10.5943/sif/5/1/22
}

\section{Traditional knowledge and use of wild mushrooms in Simbhanjyang, Makwanpur district, Central Nepal}

\section{Khadka B and Aryal HP}

Central Department of Botany, Tribhuvan University, Kathmandu, Nepal

Khadka B, Aryal HP 2020 - Traditional knowledge and use of wild mushrooms in Simbhanjyang, Makwanpur district, Central Nepal. Studies in Fungi 5(1), 406-419, Doi 10.5943/sif/5/1/22

\begin{abstract}
Mushrooms are an important source of food among different ethnic communities in Nepal and are widely collected during rainy season. This paper includes documentation of wild mushrooms in the vicinities of Simbhanjyang, Makwanpur district, central Nepal. Semi-structured open ended questionnaire and Rapid Rural Appraisal were followed to get information about edibility of wild mushrooms from local harvesters. Forty-three species of mushrooms were documented. The collected species are saprophytic, parasitic, and mycorrhizal. Ethnic communities identify edible and other useful mushroom species based on traditional knowledge transferred from their ancestors orally which was in practice and tested through generations. Edible Boletus edulis, Russula virescens and medicinal Ganoderma tsugae are some potential non-timber forest products from the study area.
\end{abstract}

Key words - Agaricomycetes - edible mushroom - ethnomycology - macrofungi - mushroom diversity

\section{Introduction}

Wild edible mushrooms are important high valued Non-Timber Forest Products (NTFPs) collected as food resource by Nepalese ethnic groups since time immemorial (Devkota 2008) and it represents an important income source for livelihoods in rural areas (Adhikari 2000, Christensen \& Larsen 2005, Devkota 2006, 2008). In different areas of Nepal and India, mushrooms are commonly regarded as "poor man's meat” (Harsh et al. 1993, Christensen et al. 2008a) whereas in the Nepalese high mountains they are considered as an important and prestigious part of the culture (Christensen et al. 2008a). Wild edible mushrooms are widely collected from lower plains to the highlands (Devkota 2017) across different parts of Nepal during rainy season (June to September) for their food value. Mushrooms are an important major source of protein that substitutes the meat in developing countries (Pandey \& Bhudathoki 2007, Giri \& Rana 2008).

The studies on Nepalese fungi began in the $19^{\text {th }}$ century with the works of Lloyd (1808) and Berkeley (1838), with the taxonomic studies on Ganoderma and Polystictus species, respectively. Further, the collection and survey on mycoflora of East Nepal was done by Hooker (1848-1854) and published by Berkeley (1854 a, b, c). Other major studies on diversity of wild mushrooms of Nepal were carried out by Pandey (1976), Waraitch \& Thind (1977), Bhandary (1980), Hijortsam \& Ryvarden (1984), Adhikari (1990, 2000), Balfour-Browne (1995), Adhikari \& Manandhar (1996), Rana \& Giri (2006), Adhikari \& Devkota (2007), Giri \& Rana (2007), Aryal et al. (2012), Jha \& Tripathi (2012) and Baral et al (2015). 
The last fungal diversity update was made by Adhikari (2018) who estimated around 2,467 fungal species in Nepal. From this number 1,271 are macrofungal species belonging to Ascomycota and Basidiomycota (Adhikari 2014). Christensen et al. (2008a) recorded 228 as edible and Adhikari (2014) recorded 100 species as poisonous and 89 as medicinal. Misidentification of wild mushrooms during harvesting season is the main cause for mushroom poisoning. The similar morphological features that some species displays creates confusion among local collectors (as genus Amanita and Russula similar in appearance, poisonous Inocybe rimosa similar in appearance with edible Russula sp); which is also a cause along with the lack of traditional techniques to identify edible mushroom to increase in the mushroom poisoning casualties during harvesting season.

One of the first ethnomycological studies in Nepal was conducted by Joshi \& Joshi (1999) in the Kathmandu and Pokhara Valley who recorded the uses of some mushrooms by the Tamang and Newar communities documenting as edibles, some species of Amanita, Boletus, Cantharellus, Hydnum, Pleurotus, Polyporus and Russula, and some species of Lycoperdon as medicinal. Adhikari et al. (2005) documented the edibility of some species of Laccaria, Lactarius, Laetiporus, Ramaria and Russula, the medical uses of species Coriolus, Daldinia, Lycoperdon, and Schizophyllum and the uses in the ignition of cigarettes with sporocarps of species of Coriolus, Ganoderma and Trametes by Newars, Tamangs and Chhetris from Lumle, Kaski district and different areas of Kathmandu district; Giri et al. (2005) recorded the edibility of some species of Boletus, Naematoloma, Russula and Tylophus by the Sherpa community in the Khumbu region in eastern Nepal; Devkota (2006) reported medicinal uses for Ophiocordyceps sinensis by Amchis and local community of Dolpa, west Nepal; Pandey et al. (2006) reported species of Grifola, Laccaria, Lactarius, Laetiporus, Ramaria and Russula as edibles, the medical use of some species of Grifola, Laetiporus, Pleurotus, Pycnoporus, Ramaria and Trametes and the ornamental uses of species of Ganoderma and Schizophyllum by Tamangs of Nepal.

The latest ethnomycological studies were carried by Christensen et al. (2008b) who documented some species of Boletus, Cantharellus, Gomphus, Helvella, Hydnum, Lactarius, Laetiporus, Lentinus, Morchella, Pleurotus, Polyporus, Ramaria, Russula and Suillus used as food by the indigenous local peoples and different ethnic communities within Annapurna Conservation Area, Nepal; Giri \& Rana (2008) reported some species of Amanita, Boletus, Chroogomphus, Ghompus, Hydnum, Hygrophorus, Leccinum, Paxillus and Ramaria as edible mushrooms, the medicinal uses of species of Lycoperdon and species of Ganoderma in decorative purpose by Sherpa community of East Nepal and Aryal \& Bhudathoki (2013) reported species of Amanita, Armellaria, Flammulina, Lentinus, Macrolepiota, Russula, Schizophyllum and Scleroderma, the use of some species of Ganoderma, Termitocyes and Volvarella in decorative purposes and species of Pycnoporus and Scleroderma as medicinal mushrooms from Rupandehi district, Nepal.

This study aims to explore the uses of mushrooms, its diversity and associated traditional knowledge among different ethnic groups inhabiting in Simbhanjyang, central Nepal.

\section{Materials \& Methods}

\section{Study Area}

The study site is in Simbhanjyang and its adjoining areas of Thaha Rural Municipality (RM) ward 3 and 4 and Bhimphedi RM ward 9. Simbhanjyang situated in Bhimphedi RM, Makwanpur district, is located in southern Nepal as in Fig. 1, $26 \mathrm{~km}$ away from Kathmandu city between the coordinates $27.5933^{\circ} \mathrm{N}$ and $85.0818^{\circ} \mathrm{E}$ with an elevation of $2488 \mathrm{~m}$ a.s.l. The vegetation is a temperate cloud forest (Miehe et al. 2015) represented by Quercus-Rhododendron forest (Quercus lanata, Q. lamellosa, Rhododendron arboreum) and pine mixed forest (Pinus wallichiana, Alnus nepalensis) with high canopy cover and litter cover. These two factors are good for mycorrhizal, saprophytic or parasitic fungus (Baral et al. 2015). The annual precipitation of about $1154.7 \mathrm{~mm}$ falls mostly from May to September. Temperatures vary from $-1.8^{\circ} \mathrm{C}$ to $11.9^{\circ} \mathrm{C}$ during the winter season, rising $18^{\circ} \mathrm{C}$ to $20.3^{\circ} \mathrm{C}$ during the summer season (Source: www.climate-data.org/). 
Simbhanjyang, Makwanpur district is inhabited by different ethnic groups as Tamang, Brahmin, Chhetri, Newar and others as Dalits. All of them are totally depended on either agriculture or livestock rearing. Some Newars and Dalits are involved in tourism and other business sectors at small scale.

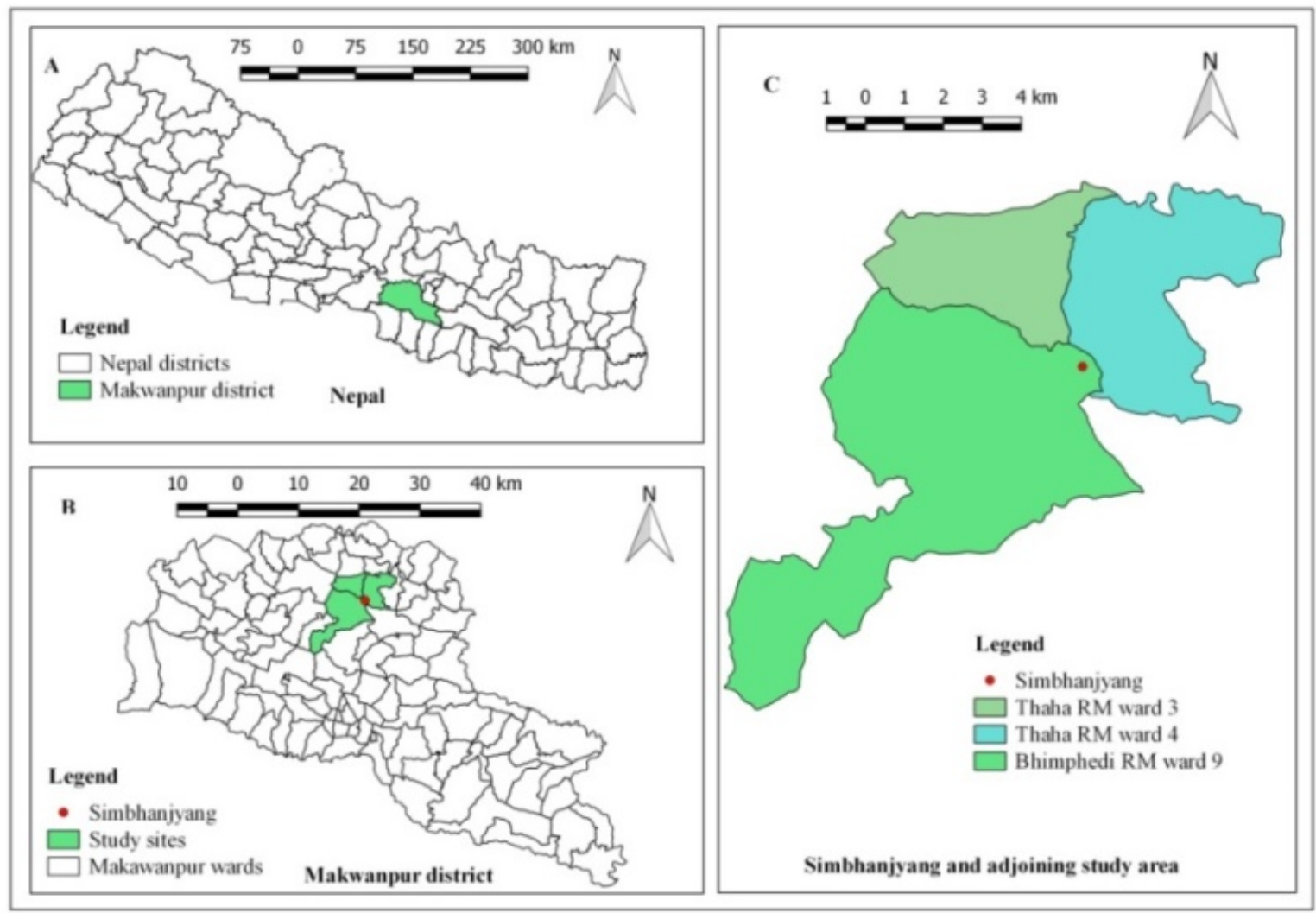

Fig. 1 - Map of study area

\section{Sampling and morphological study}

The specimens were collected in rainy season from 2017 to 2019. The mushrooms were photographed in their natural habitat and the colour, shape, elevation, ecology, and habitats of each specimen were recorded. Delicate specimens were preserved in a liquid preservative as per Hawksworth et al. (1995) (25:5:70 ml of Rectified alcohol + formalin + distilled water), hard and woody specimens were air dried. The samples were identified using previous descriptions in taxonomical works as Singer (1952), Imazeki et al. (1988), Dickinson \& Lucas (1979), Arora (1996), and Adhikari (2000, 2014). All the names and authors follow Index Fungorum (www.indexfungorum.org). The specimens were deposited in pathology laboratory at Central Department of Botany, Tribhuvan University, Kathmandu, Nepal.

\section{Ethnomycological study}

Prior consent of information (PIC) and required field permission were taken orally from the elder leader of ethnic community and forest users group. Five random individual interviews, a participatory discussions and a forest walk were done in each ethnic groups (Tamang, Chhetri and Newar) about the purpose of collecting mushrooms, cooking methods of raw mushrooms and how to identify edible and poisonous mushrooms. Rapid Rural Appraisal (RRA) and semi-structured open ended questionnaires (Martin 1995) were used. Respondents represented three ethnic groups (Tamang, Chhetri and Newar) and most ages between 20 and 50 years. Species recognition by local respondents was based on fresh samples and author's photograph. All the ethics of traditional ethnic communities and ethnomycology were followed. 


\section{Results}

\section{Diversity of wild mushrooms}

Forty-three species of mushroom were documented representing 22 families and 30 genera (Annex 2). Amanita fulva, Boletus edulis, Calocybe chrysenteron, Helvella atra, Leccinum rugosiceps, Lycoperdon perlatum, Russula cyanoxantha, Russula nigricans, and Russula rosea were some common (Fig. 2) species meanwhile Ganoderma tsugae and Ramaria aurea were rare in distribution. Among forty-three species of mushroom, based on habitat fifteen species were saprophytes, eleven were mycorrhizal and two were parasitic as well as four species were either saprophytic or parasitic and eleven species were either saprophytic or mycorrhizal.

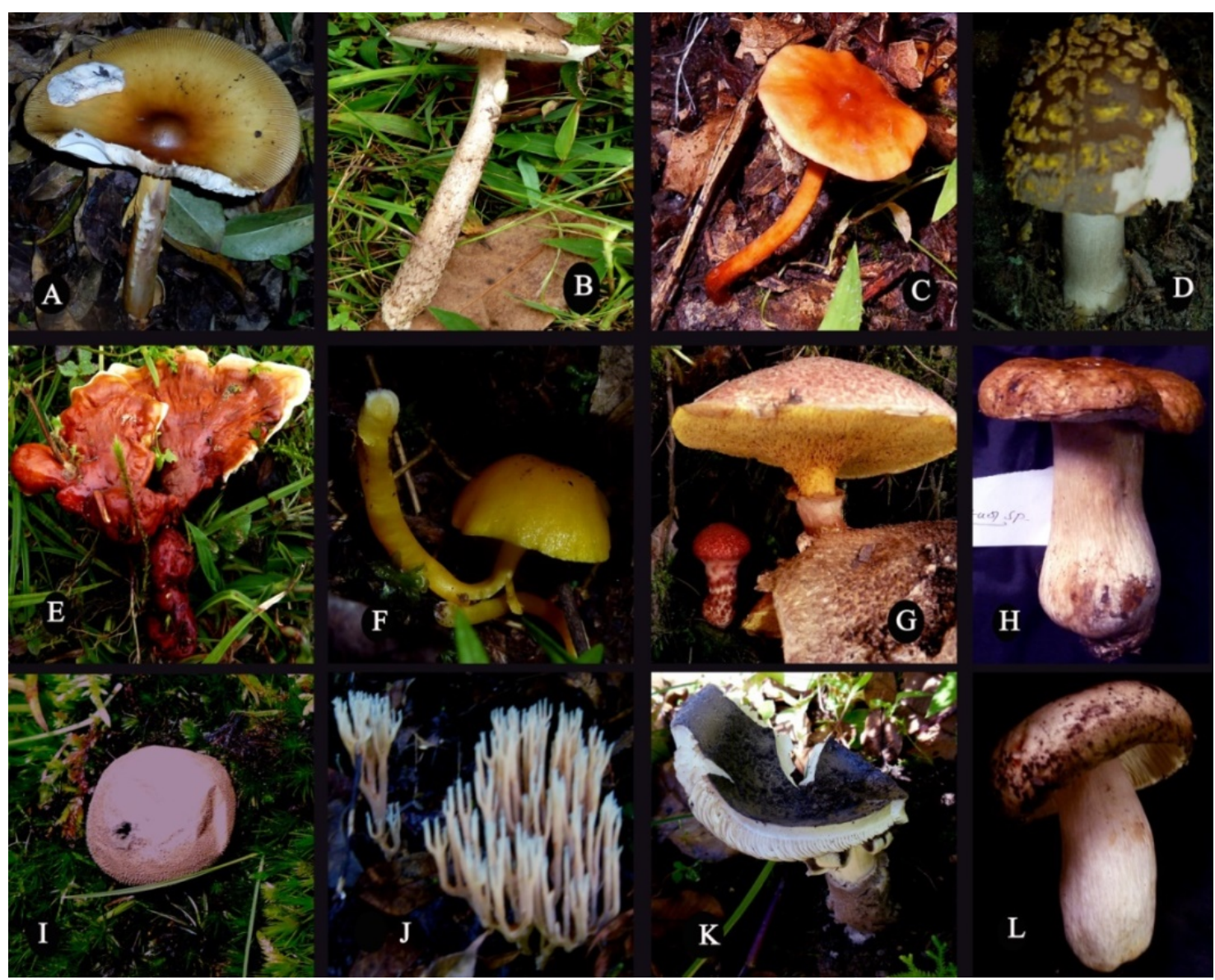

Fig. 2 - Some representative mushrooms from the study area: A) Amanita fulva Fr.,, B) Amanita longistriata S. Imai, C) Rugosomyces chrysenteron (Bull.) Bon., D) Amanita pantheriana (DC.) Krombh., E) Ganoderma tsugae Murrill, F) Hygrocybe russocoriacea (Berk. \& T. K. Mill.) P. D. Orton \& Watling,, G) Leccinum rugosiceps (Peck) Singer, H) Boletus edulis Bull., I) Lycoperdon perlatum Pers., J) Ramaria aurea (Schaeff.) Quél., K) Russula nigricans Fr. and L) Russula virescens (Schaeff.) Fr.

\section{Edible, medicinal and poisonous wild mushrooms}

The results of the questionnaires and the bibliographic research showed that twenty-five species are edible, four are medicinal and four are poisonous wild mushroom. Amanita fulva, Boletus edulis, Hydnum repandum, Laetiporus sulphureus, Marasmius oreades, Russula nigricans and Russula virescens were recorded as edible among ethnic peoples of Simbhanjyang. Amanita longistriata, Amanita pantherina, Helvella atra and Inocybe rimosa are poisonous mushrooms. Fomes fomentarius and Trametes gibbosa are non-poisonous mushroom but inedible due to its woody texture. 


\section{Indigenous knowledge on using wild mushrooms}

A total of 15 random interviews were done following the questionnaire model (Annex 1) to people from the 3 different ethnic groups within the study area. Only 9 individual collects mushroom from the wild for their own use and remaining 6 collects for selling in the local markets. The purpose of mushroom harvesting was mostly as food which they eat as curry and soup. Women and men collect mushrooms along with firewood, cattle beddings gathering, tree shoots looping and herding activities. Ethnic people were totally dependent on traditional knowledge to identify edible and poisonous mushrooms. Ethnic communities of Simbhanjyang did not collect bright coloured mushrooms. Mushroom pickers and ethnic people were well aware about the presence of poisonous mushrooms. Mostly Tamang and Newar ethnic group collect mushrooms than Chhetri whose knowledges were not so different from each other. Differences were found on the preferred edible species and mushroom picking practices. Amanita fulva, Helvella elastica, Lycoperdon perlatum and $L$. pyriforme young buds were consumed by Tamangs only whereas Hydnum repandum and Marasmius oreades were collected by Tamangs and Newars. Boletus edulis, Laetiporus sulphurous, Russula nigricans and Russula virescens were preferred by all three ethnic communities. Collection of mushrooms were either done in Awushii (no moon day) or Poornima (full moon day) based on their traditional beliefs among Tamangs and chhetris. There was no any document about the traditional knowledge and practices as this type of knowledge were transferred orally.

Chhetri and Newar communites boil it in water either with salt or ash from firewood before consuming most of the edible mushrooms to avoid possible poisoning risks. But Tamang people wash the raw mushrooms in clean water and avoid pre-boiling the raw mushroom before cooking as it decreases the natural taste of mushroom. According to some respondents from Tamang and Chhetri communites, the transfer of spores dust from poisonous mushroom to edible mushrooms naturally, the presence of poisonous small mushroom within the colony of edible mushroom and misidentification of edible mushrooms might be the cause for mushroom poisoning. So, they suggest proper identification and cleaning of collected raw mushroom before cooking is essential. Though people were dependent on their own knowledge to identify mushrooms, but this type of knowledge is not applicable for every mushroom species.

\section{Discussion}

\section{Diversity of wild mushrooms}

Forests of Simbhanjyang are rich in diversity of mushrooms as other forests within Nepal. We found twenty-five species as edible among forty-three species documented in Simbhanjyang, Makwanpur district whereas Christensen et al. (2008a) reported 228 edible mushrooms species and Adhikari (2012) reported 140 species within Nepal. Boletus edulis and Laetiporus sulphureus were commonly collected species in Symbhanjyang as in 14 districts within Nepal (Christensen et al. 2008a). Helvella elastica is not highly preferred but edible as in throughout the Himalaya (Lakhanpal 2000, Christensen et al. 2008b). Boletus edulis, Hydnum repandum, Lactarius porninsis, Laetiporus sulphureus, Leccinum rugosiceps, Marasmius oreades, Russula nigricans, Russula virescens and Suillellus queletii were commonly used in Simbhanjyang are species that are commonly used all over the world (Imazeki et al. 1988, Kuo 2007, Christensen et al. 2008a).

\section{Uses of the common mushrooms and ethnomycological knowledge}

Ethnic communities depending on forest for their livelihoods and community forest users group are the wild mushroom collectors and consumers. We recorded Amanita fulva, Boletus edulis, Hydnum repandum, Laetiporus sulphureus, Lycoperdon perlatum, L. pyriforme, Russula nigricans and Russula virescens as edible species as reported by Pandey et al. (2006) and Christensen et al. (2008a). We did not record any uses for Fomes fomentarius which was recorded for making masks by the peoples in western and eastern region of Nepal by Adhikari (2014). Immature fruiting bodies of Lycoperdon perlatum, L. pyriforme and Ramaria aurea are popular 
edible mushrooms only by Tamangs. This latter species is used by Tamangs as in other parts of the country (Joshi \& Joshi 1999) but has been reported as poisonous in Japanese literature (Imazeki et al. 1988, Adhikari 2014). Young buds of Ganoderma tsugae were edible. Ethnic peoples of Simbhanjyang were unaware about medicinal uses of Ganoderma tsugae but they found it to be a medicinal mushroom as it was collected few years ago by traders. Laetiporus sulphureus is consumed by all three ethnic groups as previously by Adhikari et al. (2005) but ethnic peoples of Simbhanjyang did not recognize as medicinal mushrooms as reported by Pandey et al. (2006). Ethnic inhabitants did not consume Exobasidium butleri which was reported edible by Adhikari et al. (2005) and Adhikari (2014) who also recorded that some people squeezed the fruiting bodies to consume the watery content. Laetiporus sulphureus, Lycoperdon perlatum and L. pyriforme are edible species and were recorded with medicinal properties by Joshi \& Joshi (1999), Adhikari et al. (2005) and Giri \& Joshi (2008). Species of Ramaria were used as food and medicine in other parts of Nepal (Adhikari et al. 2005) but it has no such uses among ethnic communities of Simbhanjyang.

Ethnic people in Simbhanjyang did not consume Lactarius porninsis, Leccinum rugosiceps and Pluteus salicinus even though these mushrooms are considered edible in different parts of the world (Wang 2000, Kuo 2007, Konuk et al. 2006). Amanita longistriata and Amanita pantherina are considered as deadly poisonous species. Amanita fulva is edible after cooking properly as it belongs to poisonous genus Amanita. Mushroom harvesting and their use have become a part of rural culture without knowing their dietary importance (Giri \& Rana 2008), anticancer, antioxidative and hypercholesterolic properties (Wong \& Cheung 2001). Ethnic communities of Simbhanjyang follow their ancestral beliefs and use Allium sativum (Lasun), Xanthoxylum armatum (Aankhe Timur) and Paris polyphylla (Satuwa) to minimize possible mushroom poisoning as reported in different earlier findings (Adhikari et al. 2005, Devkota 2008). Until now they have not any fast and strong rule to differentiate the edible and poisonous mushroom.

\section{Conclusion}

Identification of mushroom in Simbhanjyang, Makwanpur district, central Nepal is based upon their ancestral knowledge and their own experiences. Local people and indigenous communities are unaware about the presence of other edible and highly medicinal species such as Ramaria aurea and Ganoderma tsugae. Proper study, documentation, identification, sustainable harvesting awareness and cultivation of common wild species of mushrooms can support the local economy as well as conservation of wild varieties. So, proper survey based in important species of fungi and their market is important. Involvement of both the ethnic communities and mycologist with their own level of knowledge can play pivotal role for the utilization and conservation of this valuable mushrooms as resources.

\section{Acknowledgements}

We are thankful to Central Department of Botany, Tribhuvan University for their administrative support. We are cordially thankful to Mr. S.R. Bista for his help and suggestions to preserve the collected specimens. The anonymous referees are also thanked for their constructive suggestions.

\section{References}

Adhikari MK. 1990 - The genus Russula from Nepal (II). In: Cryptograms of the Himalayas, Central and Eastern Nepal. M Watanabe and SB Malla (eds.). National Science Museum, Tsukuba. Japan, pp. 101-112.

Adhikari MK. 2000 - Mushrooms of Nepal. (G Durrieu, eds.) P.U Printers. Battisputali, Kathmandu, Nepal, pp. 236.

Adhikari MK. 2012 - Researches on the Nepalese Mycoflora - 2: Checklist of macrofungi (mushrooms). Kathmandu, Nepal: KS Adhikari. 
Adhikari MK. 2014 - Mushrooms of Nepal (G Durrieu and VT Cotter, eds.). Published by KS Adhikari, Kathmandu, Nepal, pp. 340.

Adhikari MK. 2018 - Mushrooms of Nepal: A Brief Introduction (Kamala Sharma Adhikari, ed.). Published by Suman Maharjan, Balambu, Kathmandu, Nepal, pp. 90.

Adhikari MK, Devkota S. 2007 - The Clavarioid Fungi of Nepal. Bull. Dept. Pl. Res. 28, 7-22.

Adhikari MK, Devkota S, Tiwari RD. 2005 - Ethnomycological Knowledge on Uses of Wild Mushrooms in Western and Central Nepal. Our Nature 3, 13-19.

Adhikari MK, Manandhar V. 1996 - The genus Lactarius in Nepal. Advances in Botany 21, 387395.

Arora D. 1996 - Mushroom demystified: A comprehensive guide to the fleshy fungi. Barkely Ten speed press.

Aryal HP, Budathoki U. 2013 - Ethnomycological studies on some macro-fungi in Rupandehi district, Nepal. Banko Janakari, 23(1), 51-56.

Aryal HP, Budathoki U, Adhikari MK. 2012 - Mycobiodiversity in Peepaldanda Community Forest, western Tarai, Nepal. Bull. Dept. Pl. Res. 34, 13-17.

Balfour-Browne FL. 1955 - Some Himalayan fungi. Bulletin of British Museum for Natural History 1, 189-218.

Baral S, Thapa-Magar KB, Karki G, Devkota S, Shrestha BB. 2015 - Macrofungal diversity in community-managed sal (Shorea robusta) forests in central Nepal, Mycology 6(3-4), 151157.

Berkeley MJ. 1838 - Notices of British fungi [108-137]. Ann. Mag. Nat. Hist. 1, 257-264.

Berkeley MJ. 1854a - Decades XLI-XLIII. Indian Fungi. Hooker's Journal of Botany Kew Garden Misc 6 129-143.

Berkeley MJ. 1854b - Decades XLVII. XLVIII. Indian fungi. Hooker's Journal of Botany Kew Garden Misc 6, 204-212.

Berkeley MJ. 1854c - Decades XLIX-L Indian Fungi. Hookers Hooker's Journal of Botany Kew Gard Misc 6, 225-235.

Bhandary HR. 1980 - Notes on some macrofungi on Nepal. Jour. Nat. Hist. Mus. 4, 23-32.

Christensen M, Bhattarai S, Devkota S, Larsen HO. 2008a - Collection and use of wild edible fungi in Nepal. Economic Botany 62(1), 12-23.

Christensen M, Devkota S, Bhattarai S. 2008b - Use of wild edible mushrooms in the Annapurna Conservation Area, Nepal 1, 1-6.

Christensen M, Larsen HO. 2005 - How can Collection of Wild Edible Fungi Contribute to Livelihoods in Rural Areas of Nepal? Journal of Forest and Livelihood 4(2), 50-55.

Devkota S. 2006 - Yarsagumba [Cordyceps sinensis (Berk) Sacc.]; Traditional Utilization in Dolpa District, Western Nepal. Our Nature 4, 48-52.

Devkota S. 2008 - Distribution and status of highland mushrooms: A case study from Dolpa, Nepal. Jour. Nat. Hist. Mus. 23, 51-59.

Devkota S. 2017 - Edibility of Wild Mushrooms in the Context of Nepal: An appraisal of Indigenous and Local Knowledge (ILK). Knowing our Lands and Resources 10, 169-172.

Dickinson C, Lucas J. 1979 - Encyclopedia of Mushrooms. Orchid Publication, London, UK.

Giri A, Rana P. 2007 - Some higher fungi from Sagarmatha National Park (SNP) and its adjoining areas, Nepal. Scientific World 5(5), 67-74.

Giri A, Rana P. 2008 - Ethnomycological knowledge and nutritional analysis of some wild edible mushrooms of Sagarmatha National Park, Nepal. Jour. Nat. Hist. Mus. 23, 51-59.

Giri A, Rana P, Shrestha SK. 2005 - Wild Edible Mushrooms of Khumbu Region, Nepal. Journal of the Natural History Museum 22,148-156.

Harsh NSK, Rai BK, Ayachi SS. 1993 - Forest Fungi and Tribal Economy - A Case Study in Baiga Tribe of Madhya Pradesh (India). Journal of Tropical Forestry 9, 270-279.

Hawksworth DL, Kirk PM, Sutton BC, Pegler DN. 1995 - Ainsworth and Bisby's Dictionary of the fungi. Int. Myco. Inst. CAB International, London, pp. 616. 
Hijortsam K, Ryvarden L. 1984 - Some new and noteworthy Basidiomycetes (Aphyllophorales) from Nepal. Mycotaxon 20, 133-151.

Imazeki R, Otani Y, Hongo T. 1988 - Fungi of Japan. Yama-Kei Publisher, Tokyo.

Jha SN, Tripathi NN. 2012 - Diversity of macrofungi in Shivapuri National Park of Kathmandu valley, Nepal. Biological Forum: An International Journal 4(1), 27-34.

Joshi K, Joshi AR. 1999 - Ethnobotanical study of some mushrooms of two valleys (Kathmandu and Pokhara) of Nepal. Ethnobotany 11, 47-56.

Konuk M, Afyon A, Yağız D. 2006 - Chemical composition of some naturally growing and edible mushrooms. Pakistan Journal of Botany 38 (3), 799-804.

Kuo M. 2007 - 100 Edible Mushrooms. The University of Michigan Press.

Lakhanpal TN. 2000 - Wild and Cultivated mushrooms in Natural Resources and Development in Himalaya (ed.) Verma, LR Malhotra Publishing House, New Delhi (India).

Lloyd CG. 1808 - Mycological notes. Mycology.

Martin GJ. 1995 - Ethnobotany: A Methods manual. Chapman and Hall, London.

Miehe G, Miehe S, Bohner J, Baumler R et al. 2015 - Vegetation Ecology. In: Nepal: An introduction to the natural history, ecology and human environment of the Himalayas, A companion to the Flora of Nepal, (G. Miehe, C.A. Pendry and R.P. Chaudhary, eds.), Royal Botanic Garden Edinburgh, Edinburgh, UK, pp. 385-472.

Pandey BD.1976 - Survey collection preservation and identification of the mushrooms in Nepal. Nep. Jour. Agri 6,115-129.

Pandey N, Budhathoki U. 2007 - Status of ethnomycology in Nepal. Mycological research and mushroom production in Nepal, Mycol. Phytopath. Soc, pp. 51-60.

Pandey N, Devkota S, Christensen M, Budathoki U. 2006 - Use of Wild Mushrooms among the Tamangs of Nepal. Nepal Journal of Science and Technology 7, 96-104.

Rana P, Giri A. 2006 - Mushroom diversity in the Sagarmatha National Park and its buffer zone area. Banko Jankari 16(2), 17-24.

Singer R. 1952 - The Agaricales in modern taxonomy. Lilloa 22, 1-832.

Wang X. 2000 - A taxonomic study on some commercial species in the genus Lactarius (Agaricales) from Yunnan Province, China. Acta Botanica Yunnanica (in Chinese) 22(4), 419-27.

Waraitch KS, Thind KS. 1977 - Fungi of Nepal (Pezizales). Jour. Nat. Hist. Mus. 1, 21-34.

Wong WC, Cheung PCK. 2001 - Food and nutritional sciences programme. The Chinese University of Hong Kong, Shatin, New Territories, Hong Kong, China. 


\section{Annex 1}

\section{Questionnaires for documenting ethnomycological information}

Date

Locality

Name of Respondents

Sex:

a) Male

b) Female

Occupations

Cast/ Ethnicity

Education

1. Do you collect the mushroom?

2. For what purpose you collect the mushroom?

3. In which season of the year collection is done?

4. Are there any rules to follow while collecting mushrooms?

5. Where do you collect the mushrooms from?

6. Which forest is good for mushroom collection?

7. Is every mushrooms are edible?

8. Which mushrooms are highly preferred for collection?

9. Which mushroom is this as shown in the photograph or sample specimen?

10. Which one is edible, poisonous and inedible?

11. Which wood is better for mushrooms to thrive well in the wild?

12. Are there any mushroom having cultural belief and importance?

13. Do you collect the mushroom to sell in the market?

14. Who collects the mushroom?

15. Is there any medicinal use of these mushrooms and for what purpose do you use it?

16. When do you collect the mushroom?

17. How do you differentiate between edible and poisonous mushroom?

18. From whom did you get this type of knowledge about mushroom?

19. How to you collect and prepare mushrooms before eating?

20. Have you ever hear about mushroom poisoning?

21. How do you treat mushroom poisoning?

22. Is there any other use of the mushrooms?

23. Which colour mushrooms are edible?

24. Is it easy to find mushroom nowadays?

25 . What is the status of mushroom in the forest?

Further questions can be raised based on the answers of the participants, their interest and knowledge level. 
Annex 2 Mushrooms reported from Simbhanjyang in wild.

\begin{tabular}{|c|c|c|c|c|c|c|c|}
\hline S.N. & $\begin{array}{l}\text { Collection } \\
\text { Number }\end{array}$ & Name & Family & Common Name & $\begin{array}{l}\text { Ecology and Habitat } \\
\text { substratum }\end{array}$ & Edibility & Distribution in World \\
\hline 1 & BKS-5 & $\begin{array}{l}\text { Aleuria aurantia } \\
\text { (Pers.) Fuckel, } 1870\end{array}$ & Pyronemataceae & $\begin{array}{l}\text { Orange peel } \\
\text { fungus (English) }\end{array}$ & Saprobic, on moist soil & Edible & $\begin{array}{l}\text { North and South America, } \\
\text { Europe, Japan, China, India } \\
\text { and Nepal }\end{array}$ \\
\hline 2 & BKS-2 & $\begin{array}{l}\text { Amanita fulva Fr., } \\
1815\end{array}$ & Amanitaceae & $\begin{array}{l}\text { Twany grisette, orange- } \\
\text { brown ringless amanita } \\
\text { (English), Gadha khairo } \\
\text { chayu (Nepali) and } \\
\text { Tahar shyamo } \\
\text { (Tamang) }\end{array}$ & $\begin{array}{l}\text { Mycorrhizal, growing on } \\
\text { moist soil, in shady } \\
\text { places, in Oak forest }\end{array}$ & $\begin{array}{l}\text { Edible with } \\
\text { proper care }\end{array}$ & $\begin{array}{l}\text { North America, Europe, Japan } \\
\text { and Nepal }\end{array}$ \\
\hline 3 & BKS-9 & $\begin{array}{l}\text { Amanita } \\
\text { longistriata S. Imai, } \\
1938\end{array}$ & Amanitaceae & $\begin{array}{l}\text { Imai’s Slender Caesar } \\
\text { (English), Khairo bhoot } \\
\text { chyau (Nepali) }\end{array}$ & $\begin{array}{l}\text { Mycorrhizal, growing on } \\
\text { soil, in shady place under } \\
\text { canopy of mixed forest }\end{array}$ & Poisonous & $\begin{array}{l}\text { Europe, Japan, China and } \\
\text { Nepal }\end{array}$ \\
\hline 4 & BKS-31 & $\begin{array}{l}\text { Amanita pantherina } \\
\text { (DC.) Krombh., } 1846\end{array}$ & Amanitaceae & $\begin{array}{l}\text { Panther cap and false } \\
\text { blusher (English), Bhut } \\
\text { chyau (Nepali) and } \\
\text { Manga shymao } \\
\text { (Tamang) }\end{array}$ & $\begin{array}{l}\text { Mycorrhizal, on moist } \\
\text { soil in shady place, Oak } \\
\text { and Pine forest }\end{array}$ & Poisonous & $\begin{array}{l}\text { North and South America, } \\
\text { Europe, South Africa, Japan, } \\
\text { North Asia and Nepal }\end{array}$ \\
\hline 5 & BKS-5 & $\begin{array}{l}\text { Boletus edulis Bull., } \\
1782\end{array}$ & Boletaceae & $\begin{array}{l}\text { Dark cap, Tanned cep, } \\
\text { Penny bun, cep, porcino } \\
\text { or porcini (English) and } \\
\text { Pho shyamo (Tamang) }\end{array}$ & $\begin{array}{l}\text { Mycorrhizal, growing on } \\
\text { soil, under the canopy of } \\
\text { mixed forest }\end{array}$ & Edible & Cosmopolitan \\
\hline 6 & BKS-37 & $\begin{array}{l}\text { Coltricia cinnamomea } \\
\text { (Jacq.) Murrill, } 1904\end{array}$ & Hymenochaetaceae & $\begin{array}{l}\text { Coltricie, Shiny } \\
\text { cinnamon polypore } \\
\text { (English) }\end{array}$ & $\begin{array}{l}\text { Saprobic or mycorrhizal, } \\
\text { on soil in moist oak forest }\end{array}$ & Unknown & Worldwide \\
\hline 7 & BKS-4 & $\begin{array}{l}\text { Coprinellus } \\
\text { disseminates (Pers.) J. } \\
\text { E. Lange, } 1938\end{array}$ & Psathyrellaceae & $\begin{array}{l}\text { Fairy ink cap, Little } \\
\text { helmet, Fairy bonnet, } \\
\text { Trooping crumble cap } \\
\text { (English); Bagale seto- } \\
\text { kalo chyau (Nepali). }\end{array}$ & Saprobic, on soil & Unknown & Worldwide \\
\hline 8 & BKS-32 & $\begin{array}{l}\text { Crepidotus mollis } \\
\text { (Schaeff.) Staude, } \\
1857\end{array}$ & Inocybaceae & $\begin{array}{l}\text { Peeling oysterling, Jelly } \\
\text { crap, Flebby crepidotus } \\
\text { and soft slipper } \\
\text { (English). }\end{array}$ & $\begin{array}{l}\text { Saprobic, on the dead } \\
\text { trunk of oak tree }\end{array}$ & Unknown & $\begin{array}{l}\text { North America, Europe, Japan, } \\
\text { China and Nepal }\end{array}$ \\
\hline 9 & BKS-43 & $\begin{array}{l}\text { Exobasidium butleri } \\
\text { Syd. \& P. Syd., } 1912\end{array}$ & Exobasidiaceae & $\begin{array}{l}\text { Pani pokey chyau } \\
\text { (Nepali) }\end{array}$ & $\begin{array}{l}\text { Parasitic on } \\
\text { Rhododendron leaves }\end{array}$ & Edible & India, Nepal \\
\hline
\end{tabular}


Annex 2 Continued.

\begin{tabular}{|c|c|c|c|c|c|c|c|}
\hline S.N. & $\begin{array}{l}\text { Collection } \\
\text { Number }\end{array}$ & Name & Family & Common Name & $\begin{array}{c}\text { Ecology and Habitat } \\
\text { substratum }\end{array}$ & Edibility & Distribution in World \\
\hline 10 & BKS-8 & $\begin{array}{l}\text { Fomes } \\
\text { fomentarius (L.) Fr., } \\
1849\end{array}$ & Polyporaceae & $\begin{array}{l}\text { Hoof fungus, Timber } \\
\text { bracket (English); } \\
\text { Ghodatape chyau } \\
\text { (Nepali). }\end{array}$ & $\begin{array}{l}\text { Parasitic and saprobic, on } \\
\text { the trunk of oak tree }\end{array}$ & Inedible & Worldwide \\
\hline 11 & BKS-3 & $\begin{array}{l}\text { Ganoderma tsugae } \\
\text { Murrill, } 1902\end{array}$ & Ganodermataceae & $\begin{array}{l}\text { Hemlock varnish shelf } \\
\text { (English) }\end{array}$ & $\begin{array}{l}\text { Saprobic and parasitic, on } \\
\text { Pinus roxburghii trunk } \\
\text { and decaying woods }\end{array}$ & $\begin{array}{l}\text { Edible at } \\
\text { young stage }\end{array}$ & $\begin{array}{l}\text { Europe, North-eastern North } \\
\text { America, Japan and Nepal }\end{array}$ \\
\hline 12 & BKS-34 & $\begin{array}{l}\text { Gomphidius } \\
\text { maculatus (Scop.) Fr., } \\
1838\end{array}$ & Gomphidiaceae & & $\begin{array}{l}\text { Saprobic or mycorrhizal, } \\
\text { on moist soil, in oak } \\
\text { forest }\end{array}$ & Edible & North America, Europe, Nepal \\
\hline 13 & BKS-39 & $\begin{array}{l}\text { Helvella atra J. } \\
\text { König, } 1770\end{array}$ & Helvellaceae & $\begin{array}{l}\text { Dark elfin saddle } \\
\text { (English) }\end{array}$ & $\begin{array}{l}\text { Saprobic or mycorrhizal, } \\
\text { on the mossy rocks, in } \\
\text { canopy of mixed forest }\end{array}$ & Poisonous & $\begin{array}{l}\text { North America, Europe, Japan, } \\
\text { China, India and Nepal }\end{array}$ \\
\hline 14 & BKS-36 & $\begin{array}{l}\text { Helvella elastica } \\
\text { Bull., } 1785\end{array}$ & Helvellaceae & $\begin{array}{l}\text { Flexible Helvella, } \\
\text { elastic saddlem, brown } \\
\text { elfin saddle, elastic } \\
\text { brain fungus (English) }\end{array}$ & $\begin{array}{l}\text { Saprobic or mycorrhizal, } \\
\text { on moist soil among } \\
\text { bryophytes under canopy } \\
\text { of oak forest }\end{array}$ & Edible & $\begin{array}{l}\text { North America, Europe, Japan, } \\
\text { China, India and Nepal }\end{array}$ \\
\hline 15 & BKS-10 & Helvella sp & Helvellaceae & & $\begin{array}{l}\text { Saprobic or mycorrhizal, } \\
\text { on moist soil among } \\
\text { mosses }\end{array}$ & Unknown & Europe, Asia, Nepal \\
\hline 16 & BKS-20 & $\begin{array}{l}\text { Humaria } \\
\text { hemisphaerica (F. H. } \\
\text { Wigg.) Fuckel, } 1870\end{array}$ & Pyronemataceae & $\begin{array}{l}\text { Hairy fairy cup, Brown- } \\
\text { haired fairy cup or } \\
\text { Glazed cup (English) }\end{array}$ & $\begin{array}{l}\text { Saprobic and } \\
\text { mycorrhizal, on soil }\end{array}$ & Unknown & $\begin{array}{l}\text { Europe, North America, Japan, } \\
\text { India and Nepal. }\end{array}$ \\
\hline 17 & BKS-33 & $\begin{array}{l}\text { Hydnum repandum L., } \\
1753\end{array}$ & Hydnaceae & $\begin{array}{l}\text { Sweet tooth, wood } \\
\text { hedgehog or hedgehog } \\
\text { mushroom (English), } \\
\text { Chwali Ura shyamo } \\
\text { (Tamang) }\end{array}$ & $\begin{array}{l}\text { Mycorrhizal, in Oak } \\
\text { forest, on soil }\end{array}$ & Edible & $\begin{array}{l}\text { Europe, North America, South } \\
\text { Australia, Japan and Nepal }\end{array}$ \\
\hline 18 & BKS-13 & $\begin{array}{l}\text { Hygrocybe } \\
\text { conica (Schaeff.) P. } \\
\text { Kumm., } 1871\end{array}$ & Hygrophoraceae & $\begin{array}{l}\text { Witch's hat, conical } \\
\text { wax cap or conical } \\
\text { slimy cap (English), } \\
\text { Chuche rato kalo chyau } \\
\text { (Nepali) }\end{array}$ & $\begin{array}{l}\text { Mycorrhizal or saprobic, } \\
\text { on soil in moist oak forest }\end{array}$ & Unknown & $\begin{array}{l}\text { Europe, North and South } \\
\text { America, Australia New } \\
\text { Zealand, Japan, China, India } \\
\text { and Nepal }\end{array}$ \\
\hline
\end{tabular}


Annex 2 Continued.

\begin{tabular}{|c|c|c|c|c|c|c|c|}
\hline S.N. & $\begin{array}{c}\text { Collection } \\
\text { Number }\end{array}$ & Name & Family & Common Name & $\begin{array}{c}\text { Ecology and Habitat } \\
\text { substratum }\end{array}$ & Edibility & Distribution in World \\
\hline 19 & BKS-14 & $\begin{array}{l}\text { Hygrocybe } \\
\text { miniata (Fr.) P. } \\
\text { Kumm., } 1871\end{array}$ & Hygrophoraceae & $\begin{array}{l}\text { Vermilion waxcap, } \\
\text { Fading scarlet wax cap } \\
\text { (English) and Wala } \\
\text { shyamo (Tamang). }\end{array}$ & $\begin{array}{l}\text { Saprobic, on soil in moist } \\
\text { oak forest }\end{array}$ & Edible & $\begin{array}{l}\text { Europe, North America, Japan, } \\
\text { China, India and Nepal }\end{array}$ \\
\hline 20 & BKS-12 & $\begin{array}{l}\text { Hygrocybe } \\
\text { punicea (Fr.) P. } \\
\text { Kumm., } 1871\end{array}$ & Hygrophoraceae & $\begin{array}{l}\text { Crimson or Scarlet } \\
\text { Waxy Cap (English) }\end{array}$ & $\begin{array}{l}\text { Saprobic, on soil in moist } \\
\text { oak forest }\end{array}$ & Edible & $\begin{array}{l}\text { Europe, North America, Japan, } \\
\text { China, India and Nepal }\end{array}$ \\
\hline 21 & BKS-42 & $\begin{array}{l}\text { Hygrocybe } \\
\text { russocoriacea (Berk. } \\
\text { \& T. K. Mill.) P. D. } \\
\text { Orton \& Watling, } \\
1969\end{array}$ & Hygrophoraceae & $\begin{array}{l}\text { Cedarwood Waxcap } \\
\text { (English) }\end{array}$ & $\begin{array}{l}\text { Saprobic, on soil in oak } \\
\text { forest }\end{array}$ & Unknown & Europe and Nepal \\
\hline 22 & BKS-26 & $\begin{array}{l}\text { Inocybe rimosa (Bull.) } \\
\text { P. Kumm., } 1871\end{array}$ & Inocybaceae & Silken haired (English) & $\begin{array}{l}\text { Mycorrhizal, on moist } \\
\text { soil under canopy of oaks }\end{array}$ & Poisonous & Europe and Nepal \\
\hline 23 & BKS-27 & $\begin{array}{l}\text { Inonotus } \\
\text { hispidus (Bull.) P. } \\
\text { Karst., } 1879\end{array}$ & Hymenochaetaceae & $\begin{array}{l}\text { Shaggy bracket } \\
\text { (English) }\end{array}$ & $\begin{array}{l}\text { Parasitic, on oak tree } \\
\text { stump }\end{array}$ & Unknown & $\begin{array}{l}\text { North America, Europe, Japan, } \\
\text { India and Nepal. }\end{array}$ \\
\hline 24 & BKS-38 & $\begin{array}{l}\text { Lactarius } \\
\text { porninsis Rolland, } \\
1890\end{array}$ & Russulaceae & $\begin{array}{l}\text { Larch milkcap } \\
\text { (English) }\end{array}$ & $\begin{array}{l}\text { Mycorrhizal, on moist } \\
\text { forest under the canopy } \\
\text { of mixed forest }\end{array}$ & Edible & $\begin{array}{l}\text { Europe, Japan, China and } \\
\text { Nepal. }\end{array}$ \\
\hline 25 & BKS-41 & $\begin{array}{l}\text { Laetiporus } \\
\text { sulphureus (Bull.) } \\
\text { Murrill, } 1920\end{array}$ & Fomitopsidaceae & $\begin{array}{l}\text { Chicken of the wood, } \\
\text { Sulfur shelf (English), } \\
\text { Rato khashru chyau, } \\
\text { Bhalu chyau, Rato } \\
\text { chayu (Nepali) and } \\
\text { Phenji thanga shyamo } \\
\text { (Tamang) }\end{array}$ & $\begin{array}{l}\text { Saprobic and parasitic, on } \\
\text { oak tree trunk }\end{array}$ & Edible & Worldwide \\
\hline 26 & BKS-15 & $\begin{array}{l}\text { Leccinum } \\
\text { rugosiceps (Peck) } \\
\text { Singer, } 1945\end{array}$ & Boletaceae & $\begin{array}{l}\text { Wrinkled Leccinum } \\
\text { (English) }\end{array}$ & $\begin{array}{l}\text { Mycorrhizal, on soil in } \\
\text { moist dark Oak forest }\end{array}$ & Edible & $\begin{array}{l}\text { Europe, North and South } \\
\text { America, Japan and Nepal }\end{array}$ \\
\hline 27 & BKS-30 & $\begin{array}{l}\text { Lepista nuda (Bull.) } \\
\text { Cooke, } 1871\end{array}$ & Tricholomataceae & Wood blewit (English). & Saprobic, on moist soil & Unknown & $\begin{array}{l}\text { North America, Europe, } \\
\text { Australia and Nepal }\end{array}$ \\
\hline 28 & BKS-16 & $\begin{array}{l}\text { Lycoperdon } \\
\text { perlatum Pers., } 1796\end{array}$ & Agaricaceae & $\begin{array}{l}\text { Warted puffball, gem- } \\
\text { studded puffball or }\end{array}$ & $\begin{array}{l}\text { Saprobic, growing among } \\
\text { mosses on moist soil }\end{array}$ & $\begin{array}{l}\text { Edible when } \\
\text { young }\end{array}$ & $\begin{array}{l}\text { North America, Europe, } \\
\text { Tasmania, Africa, Australia, }\end{array}$ \\
\hline
\end{tabular}


Annex 2 Continued.

\begin{tabular}{|c|c|c|c|c|c|c|c|}
\hline S.N. & $\begin{array}{l}\text { Collection } \\
\text { Number }\end{array}$ & Name & Family & Common Name & $\begin{array}{c}\text { Ecology and Habitat } \\
\text { substratum }\end{array}$ & Edibility & Distribution in World \\
\hline & & & & $\begin{array}{l}\text { the devil's snuff-box } \\
\text { (English), Patkey and } \\
\text { Phusphusey Chyau } \\
\text { (Nepali) }\end{array}$ & under canopy of oak trees & & Japan, China, India, and Nepal \\
\hline 29 & BKS-21 & $\begin{array}{l}\text { Lycoperdon } \\
\text { pyriforme Schaeff., } \\
1774\end{array}$ & Agaricaceae & $\begin{array}{l}\text { Pear-shaped } \\
\text { puffball or stump } \\
\text { puffball (Englilsh), } \\
\text { Patkey and Phusphusey } \\
\text { Chyau (Nepali) }\end{array}$ & $\begin{array}{l}\text { Saprobic, on moist soil } \\
\text { among mosses }\end{array}$ & $\begin{array}{l}\text { Edible when } \\
\text { young }\end{array}$ & $\begin{array}{l}\text { Europe, Sino- Japan, Central } \\
\text { and South East Asia, North } \\
\text { America, Australia, Africa, } \\
\text { Tasmania, New Zealand, } \\
\text { Japan, Australia, China, India } \\
\text { and Nepal }\end{array}$ \\
\hline 30 & BKS-18 & $\begin{array}{l}\text { Marasmius } \\
\text { oreades (Bolton) Fr., } \\
1836\end{array}$ & Marasmiaceae & $\begin{array}{l}\text { Fairy ring champignon, } \\
\text { Fairy ring mushroom, } \\
\text { Scotch bonnet } \\
\text { (English), Boody chyau } \\
\text { (Nepali) }\end{array}$ & Saprobic, on soil & Edible & $\begin{array}{l}\text { North temperate region } \\
\text { including Nepal }\end{array}$ \\
\hline 31 & BKS-24 & $\begin{array}{l}\text { Mycena galericulata } \\
\text { (Scop.) Gray, } 1821\end{array}$ & Mycenaceae & $\begin{array}{l}\text { Bonnet } \\
\text { Mycena, common } \\
\text { bonnet, the toque } \\
\text { Mycena, or the rosy-gill } \\
\text { fairy helmet (English) }\end{array}$ & $\begin{array}{l}\text { Saprobic, growing on } \\
\text { moist soil and decaying } \\
\text { wooden logs }\end{array}$ & Edible & $\begin{array}{l}\text { North America, Europe, Japan, } \\
\text { China, India and Nepal }\end{array}$ \\
\hline 32 & BKS-25 & $\begin{array}{l}\text { Phylloporus bellus } \\
\text { (Massee) Corner, } \\
1971\end{array}$ & Boletaceae & & $\begin{array}{l}\text { Mycorrhizal, on soil in } \\
\text { moist oak forest }\end{array}$ & Unknown & $\begin{array}{l}\text { Europe, Singapore, Japan, } \\
\text { Malaysia, India, Bhutan and } \\
\text { Nepal }\end{array}$ \\
\hline 33 & BKS-28 & $\begin{array}{l}\text { Pluteus salicinus } \\
\text { (Pers.) P. Kumm., } \\
1871\end{array}$ & Pluteaceae & $\begin{array}{l}\text { Knackers Crumpet } \\
\text { (English) }\end{array}$ & $\begin{array}{l}\text { Saprobic, on soil under } \\
\text { the canopy of mixed oak } \\
\text { forest }\end{array}$ & Edible & Europe, India and Nepal \\
\hline 34 & BKS-19 & $\begin{array}{l}\text { Ramaria aurea } \\
\text { (Schaeff.) Quél., } 1888\end{array}$ & Gomphaceae & $\begin{array}{l}\text { Golden Coral, Yellow } \\
\text { Coral, Coral mushroom } \\
\text { (English), Thakre chyau } \\
\text { (Nepali) }\end{array}$ & $\begin{array}{l}\text { Saprobic or mycorrhizal, } \\
\text { on soil with high litter in } \\
\text { Oak forest }\end{array}$ & Edible & $\begin{array}{l}\text { Europe, North America, Japan, } \\
\text { India and Nepal }\end{array}$ \\
\hline 35 & BKS-7 & $\begin{array}{l}\text { Rugosomyces } \\
\text { chrysenteron (Bull.) } \\
\text { Bon, } 1991\end{array}$ & Lyophyllaceae & $\begin{array}{l}\text { Yellow domecap } \\
\text { (English) }\end{array}$ & $\begin{array}{l}\text { Mycorrhizal, on moist } \\
\text { soil, under canopy of Oak } \\
\text { forest }\end{array}$ & Edible & $\begin{array}{l}\text { Europe, North America and } \\
\text { Northern Asia including Nepal }\end{array}$ \\
\hline
\end{tabular}


Annex 2 Continued.

\begin{tabular}{|c|c|c|c|c|c|c|c|}
\hline S.N. & $\begin{array}{c}\text { Collection } \\
\text { Number }\end{array}$ & Name & Family & Common Name & $\begin{array}{c}\text { Ecology and Habitat } \\
\text { substratum }\end{array}$ & Edibility & Distribution in World \\
\hline 36 & BKS-35 & $\begin{array}{l}\text { Russula amoena } \\
\text { Quél., } 1881\end{array}$ & Russulaceae & $\begin{array}{l}\text { Russula agreeable } \\
\text { (English) }\end{array}$ & $\begin{array}{l}\text { Saprophytic, on soil in } \\
\text { moist shady place, in } \\
\text { mixed forest }\end{array}$ & Unknown & $\begin{array}{l}\text { North America, Europe, Japan, } \\
\text { China and Nepal }\end{array}$ \\
\hline 37 & BKS-11 & $\begin{array}{l}\text { Russula } \\
\text { cyanoxantha } \\
\text { (Schaeff.) Fr., } 1863\end{array}$ & Russulaceae & $\begin{array}{l}\text { Variable Russula, } \\
\text { Charcoal burner or } \\
\text { Forked gill Russula } \\
\text { (English) }\end{array}$ & $\begin{array}{l}\text { Saprobic or mycorrhizal, } \\
\text { on soil in moist shady } \\
\text { place, in mixed forest }\end{array}$ & Edible & $\begin{array}{l}\text { Growing on soil in moist } \\
\text { shady place, in mixed forest }\end{array}$ \\
\hline 38 & BKS-40 & $\begin{array}{l}\text { Russula fragilis Fr., } \\
1838\end{array}$ & Russulaceae & $\begin{array}{l}\text { Fragile brittle gill, Fragile } \\
\text { Russula (English) }\end{array}$ & $\begin{array}{l}\text { Saprobic, on moist soil in } \\
\text { oak forest }\end{array}$ & Inedible & $\begin{array}{l}\text { North America, Europe, Japan, } \\
\text { China, India and Nepal }\end{array}$ \\
\hline 39 & BKS-21 & $\begin{array}{l}\text { Russula } \\
\text { nigricans Fr., } 1838\end{array}$ & Russulaceae & $\begin{array}{l}\text { Blackening brittle } \\
\text { gill or blackening } \\
\text { Russula (English), } \\
\text { Haandi chyau(Nepali) }\end{array}$ & $\begin{array}{l}\text { Mycorrhizal or } \\
\text { saprophytic, on moist } \\
\text { shady place }\end{array}$ & Edible & $\begin{array}{l}\text { Europe, North America, Japan } \\
\text { and Nepal }\end{array}$ \\
\hline 40 & BKS-17 & $\begin{array}{l}\text { Russula rosea Pers., } \\
1796\end{array}$ & Russulaceae & $\begin{array}{l}\text { Beautiful Russula, Rosy } \\
\text { Russula, Rosy brittle gill } \\
\text { (English), Raktey shyamo } \\
\text { (Nepali) }\end{array}$ & $\begin{array}{l}\text { Saprobic, on soil in } \\
\text { shady place }\end{array}$ & Edible & $\begin{array}{l}\text { Europe, North America, Japan, } \\
\text { China and Nepal }\end{array}$ \\
\hline 41 & BKS-23 & $\begin{array}{l}\text { Russula } \\
\text { virescens (Schaeff.) } \\
\text { Fr., } 1836\end{array}$ & Russulaceae & $\begin{array}{l}\text { Green-cracking } \\
\text { Russula, quilted green } \\
\text { Russula, or green brittle } \\
\text { gill (English), Maili } \\
\text { shyamo (Tamang) }\end{array}$ & $\begin{array}{l}\text { Mycorrhizal or saprobic, } \\
\text { on soil in moist shady } \\
\text { place in Oak forest }\end{array}$ & Edible & $\begin{array}{l}\text { Europe, North America, Japan, } \\
\text { China and Nepal }\end{array}$ \\
\hline 42 & BKS-6 & $\begin{array}{l}\text { Suillellus } \\
\text { queletii (Schulzer) } \\
\text { Vizzini, Simonini \& } \\
\text { Gelardi, } 2014\end{array}$ & Boletaceae & $\begin{array}{l}\text { Deceiving bolete } \\
\text { (English) }\end{array}$ & $\begin{array}{l}\text { Mycorrhizal, growing on } \\
\text { moist soil under the } \\
\text { canopy of mixed forest }\end{array}$ & Edible & $\begin{array}{l}\text { Europe, North America, North } \\
\text { Asia and Nepal }\end{array}$ \\
\hline 43 & BKS-29 & $\begin{array}{l}\text { Trametes } \\
\text { gibbosa (Pers.) Fr., } \\
1838\end{array}$ & Polyporaceae & $\begin{array}{l}\text { Lumpy bracket, Gibbous } \\
\text { polypore (English). }\end{array}$ & $\begin{array}{l}\text { Saprobic and parasitic, on } \\
\text { the trunk of oak tree }\end{array}$ & Unknown & $\begin{array}{l}\text { North America, Europe, Japan, } \\
\text { China, India and Nepal }\end{array}$ \\
\hline
\end{tabular}

